\title{
Varietal Response to Sour Bunch Rot in Polish Grapevine Genetic Resources
}

\author{
Jerzy Lisek *(D) and Anna Lisek (1)
}

Citation: Lisek, J.; Lisek, A. Varietal Response to Sour Bunch Rot in Polish Grapevine Genetic Resources.

Agronomy 2021, 11, 1537. https://

doi.org/10.3390/agronomy11081537

Academic Editors: Nikolaos

Nikoloudakis and Iakovos Pantelides

Received: 17 June 2021

Accepted: 29 July 2021

Published: 31 July 2021

Publisher's Note: MDPI stays neutral with regard to jurisdictional claims in published maps and institutional affiliations.

Copyright: (c) 2021 by the authors. Licensee MDPI, Basel, Switzerland. This article is an open access article distributed under the terms and conditions of the Creative Commons Attribution (CC BY) license (https:// creativecommons.org/licenses/by/ $4.0 /)$.
The National Institute of Horticultural Research, Konstytucji 3 Maja 1/3 Str., 96-100 Skierniewice, Poland; anna.lisek@inhort.pl

* Correspondence: jerzy.lisek@inhort.pl

\begin{abstract}
The aim of this study was to assess the resistance to sour rot of twenty-eight valuable cultivars of grapevine for wine production and twenty-five cultivars of table grapevine with diverse geographic and genetic origins, and to explain the causes of varied resistance based on the features related to the morphology, biology and ecology of assessed genotypes. The study was conducted for six years in the grapevine field collection of the National Institute of Horticultural Research in Skierniewice (Poland, latitude 51.9627 N, longitude 20.1666 E). Sour rot was severe in three seasons with abundant rainfall during the berry ripening stage. The number of wine and table cultivars in particular classes of resistance (mean value for three years) was as follows: very little or little-9 (wine) and 9 (table), medium-9 (wine) and 3 (table), high or very high-10 (wine) and 13 (table). The severity of bunch sour rot was positively correlated with single berry weight (moderate or weak correlation), bunch density and single bunch weight (very weak or weak correlation), and negatively correlated with thickness of berry skin (strong correlation) and the time of the beginning of veraison (weak correlation). Cultivars that were characterized by such agrobiological and ecological features as easy detachment of the berry from the pedicel, sensitivity to berry skin cracking, frequent damage to the skin by insects, and sensitivity to sunburn, were more heavily exposed to sour rot.
\end{abstract}

Keywords: assessment; central europe; cluster; collection; field; resistance; rotting; Vitis spp.

\section{Introduction}

Climate change is widening the grapevine-growing zone in Europe and North America further north, compared to traditional wine-growing regions [1,2]. The area above latitude $50^{\circ} \mathrm{N}$ is described in viticulture as the cool climate zone. Poland, located in Central Europe, belongs to this zone. The vines are threatened by unfavorable climatic conditions-a relatively short frost-free period, low winter temperatures, frosts during the growing season, extreme weather phenomena (hail, prolonged rain, heat) and harmful organisms, including plant pathogens and pests. The assessment of genetic resources has shown that over the past decades, the frequency of grapevine infection by sour rot has increased in Poland.

Berries infected with sour rot turn pinky-brown in white varieties and purple-brown in red varieties [3]. Sour rot is a wet-type rot. The pulp is leaks from infected berries, which remain hollow, and some berries detach from the pedicel [4]. It is distinguished from other types of rot by the distinct smell of vinegar or acetone emitted by the infected fruit and the absence of fungal spores (the gray, velvety fuzz in the case of Botrytis cinerea) on the surface of the berries. Although in later stages it may be associated with rot caused by fungi, double (secondary) infection of sour rot and botrytis are rarely observed together $[5,6]$. Sour rot causes a spike in volatile acidity, which can lead to off-tasting wine $[7,8]$. Sour rot is caused by yeasts, acetic acid bacteria and Drosophila sp. flies [3,6,9-11]. Various species of yeast have been identified on the grapevine berries affected by sour rot (Hanseniaspora uvarum, Aureobasidium pullulans, Rhodotorula, Cryptococcus, Metschnikowia, Pichia, Zygosaccharomyces genus [12-15] among others), as well as acetic acid bacteria from Acetobacter spp. and 
Gluconobacter spp. [16,17]. Drosophila melanogaster is always associated with sour rot $[3,4,9]$ and is an important vector of the disease $[6,7,11,17]$. The yeasts and bacteria associated with sour rot cannot penetrate intact skin and must come in contact with the pulp through wounds $[3,7,10]$. Sour rot also begins at the place where the berry is attached to the pedicel [3]. Skin damage is caused by biotic factors, including fungal pathogens such as Botrytis cinerea [9] and Erisiphe necator [18]; birds and insects, including berry moths, honey bees, wasps [5-7,11], Drosophila suzukii [19] and abiotic factors, including hail, sunburn, water stress, and wet weather, all of which lead to microfissures and cracking of berry skin $[3,16]$.

Berries become highly susceptible to infections when the extract reaches $15^{\circ}$ Brix. Sour rot develops rapidly and severely at temperatures between 20 and $25^{\circ} \mathrm{C}$, moderately at 15 to $20^{\circ} \mathrm{C}$, and barely develops at temperature of 10 to $15^{\circ} \mathrm{C}$ [5]. Sour rot incidence and severity in $V$. vinifera $\mathrm{cv}$. 'Riesling' increased with mean air temperature and with total rainfall during the period of ripening, between veraison and harvest [17]. This disease is particularly widespread in wet, humid areas such as the Ontario region in Canada [17] and the Eastern United States [20].

Varietal differences in susceptibility of grapes to bunch rots may arise from either morphological, anatomical or physiological sources. The mechanism of resistance has been studied mainly in the rotting of clusters caused by fungal pathogens. Resistance to Rhizopus stolonifer, one of the pathogens causing grape rot, is related to the thickness of the skin, which depends on the number of cell layers and cell density in the epidermis and hypodermis; the angle formed between the fruit and the pedicel; and tannin and phytoalexin content [21]. Resistance to Botrytis cinerea, which causes causing gray mold, depends on the density of berries within a cluster, number of pores and lenticels on the berry surface, thickness and number of cell layers in the epidermis and external hypodermis; amount of cuticle and wax, berry skin protein content, total phenolic content of the skin before and after B. cinerea inoculation, and catechin and trans- and cis-resveratrol contents [22]. The degree of sensitivity to gray mold is related to the architecture of the bunch, where tight clusters are more affected than loose ones. They are determined by the following characteristics, ranked in order of importance: weight of clusters, the ratio of interior to exterior berries, and the number of berries per centimeter of rachis [23]. One of the 14 clones of cultivar Albariño that were studied, with the shortest pedicels and the smallest berries, was clearly more resistant to B. cinerea [24].

Thin-skinned, tight-clustered cultivars, such as 'Riesling' [5,25], 'Baco Noir', 'Pinot Noir', 'Pinot Gris', 'Gamay' and 'Gewürztraminer' [5] are considered particularly susceptible to sour rot. Hybrid cultivars 'Seyval', 'Valvin Muscat', 'Traminette', and 'Chardonel' are also known to be susceptible [26]. Field observations of 'Chardonnay', classified as sensitive [5], suggest that clones can vary in their susceptibility to sour rot, possibly related to cluster morphology [20]. Thin-skinned, tightly packed cultivars such as 'Vignoles', 'Sauvignon blanc', 'Blanc du Bois', 'Muscat Ottonel', and 'Vidal Blanc' have been observed to be more susceptible to sour rot compared to cultivars that are thick skinned and loose clustered like vinifera cultivars 'Petit Manseng', 'Petit Verdot' and 'Cabernet Sauvignon' and hybrid cultivars 'Chambourcin', 'Chardonel', 'Norton' and 'Lomanto' [20].

The aim of the present research was to assess the resistance to sour rot of newly introduced and traditionally grown wine and table cultivars and to verify data on the resistance of commonly grown cultivars, obtained in other, distant viticulture regions. Due to different ecological conditions in different growing regions, an important aspect of the research was to establish relations in the level of resistance between cultivars, including reference cultivar, as which can be considered 'Pinot Noir' and 'Riesling', both defined as sensitive to sour rot. The purpose of the research was to obtain results useful in practical recommendations for grapevine growers regarding the choice of varieties for planting and to explain the reasons of varied resistance to sour rot based on features related to the morphology, biology and ecology of assessed genotypes. 


\section{Materials and Methods}

\subsection{Site, Grapevines and Cultivars Characteristics}

The assessment of bunch sour rot was carried out in years 2015-2020 in the grapevine field collection of the National Institute of Horticultural Research in Skierniewice (Poland, latitude $51.9627^{\circ} \mathrm{N}$, longitude $20.1666^{\circ} \mathrm{E}$ ), located on a luvisol soil, which was slightly acidic ( $\mathrm{pH}$ 6.3) and containing 1.3\% of organic matter. Each genotype under research was represented by three, at least 5 years old (in 2015) vines, planted at the spacing of $2.5 \times 1 \mathrm{~m}$ and maintained in the form of a low head with a trunk 0.15-0.2 $\mathrm{m}$ high and 3-5 spurs pruned into $2-3$ buds ( $6-10$ young shoots per vine). In July, young shoots were pruned above the 10th-12th leaf past the last cluster of grapes. Lateral shoots were removed or shortened regularly. Fertilization and plant protection were carried out according to current recommendations for commercial vineyards. Mineral fertilization was carried out with 'Azofoska', a multi-component fertilizer containing macronutrients N, P, K, Mg and micronutrients $\mathrm{Cu}, \mathrm{Zn}, \mathrm{Mn}, \mathrm{B}, \mathrm{Mo}$; and triple superphosphate (P); this was applied in spring, at the beginning of April. Half of the necessary nitrogen dose was applied in the first half of June in the form of calcium nitrate. The annual dose of macronutrients was $\mathrm{N}: 40 \mathrm{~kg} \mathrm{ha}^{-1}$, P: $30 \mathrm{~kg} \mathrm{ha}^{-1}, \mathrm{~K}: 100 \mathrm{~kg} \mathrm{ha}^{-1}$. Chemical protection against fungal diseases was carried out with the use of fungicides containing active ingredients belonging to different chemical groups and with a different mode of action: copper, sulphur (2 treatments per season by each agent), mancozeb+metalaxyl, pyraclostrobin+boscalid, cyprodynil+fludioxonil and penconazole (optionally, 1-2 treatments per season by product, depending on the weather). No insecticides limiting insects, including Drosophila flies, or antimicrobials limiting yeasts and acetic acid bacteria were used in the collection. Vines were covered for winter (December) with cereal straw (mounds of $0.4 \mathrm{~m}$ ). Sour rot severity was assessed in years characterized by weather conditions in the period June-October, specified in the Table 1.

Table 1. Climatic conditions in Skierniewice in the period June-October.

\begin{tabular}{|c|c|c|c|c|c|c|c|c|c|c|}
\hline \multirow{2}{*}{ Year } & \multicolumn{5}{|c|}{ Average Monthly Air Temperature at the Height of $2.0 \mathrm{~m}\left({ }^{\circ} \mathrm{C}\right)$} & \multicolumn{5}{|c|}{ Monthly Sum of Rainfall (mm) } \\
\hline & Jun & Jul & Aug & Sept & Oct & Jun & Jul & Aug & Sept & Oct \\
\hline 2015 & 16.4 & 19.2 & 21.3 & 14.6 & 6.8 & 40.0 & 45.4 & 4.2 & 2.8 & 64.4 \\
\hline 2016 & 18.2 & 18.7 & 17.9 & 14.9 & 7.1 & 150.9 & 103.8 & 0.2 & 0.8 & 32.6 \\
\hline 2017 & 17.5 & 18.2 & 18.9 & 13.3 & 9.6 & 149.8 & 51.8 & 71.8 & 249.4 & 77.6 \\
\hline 2018 & 18.2 & 20.1 & 19.9 & 14.9 & 9.5 & 39.4 & 118.8 & 60.6 & 76,0 & 0,4 \\
\hline 2019 & 21.6 & 18.2 & 19.7 & 13.8 & 10.2 & 46.2 & 55.4 & 77.8 & 82.8 & 21.6 \\
\hline 2020 & 17.9 & 18.2 & 19.1 & 14.4 & 9.9 & 105.2 & 0.0 & 0.0 & 0.0 & 127.6 \\
\hline $\begin{array}{c}\text { Average } \\
1991-2010\end{array}$ & 16.8 & 19.2 & 18.2 & 13.9 & 8.2 & 67.3 & 68.2 & 54.2 & 46.5 & 37.6 \\
\hline
\end{tabular}

Twenty-eight valuable cultivars of grapevine for wine production and twenty-five cultivars of table grapevine with diverse geographic and genetic origins and different resistances to bunch sour rot were selected for the presentation of the study results out of the overall 350 genotypes represented in the collection. From among wine cultivars, eleven belonged to Vitis vinifera, three to interspecific hybrids and fourteen to inter-intraspecific hybrids. Inter-intraspecific (intra-interspecific) hybrids were isolated into a separate group [27] or classified as Vitis vinifera cultivars [28]. Table cultivars belonged to interspecific hybrids, except for one-'Chasselas Dore', classified as V. vinifera. Information on wine and table cultivars, such as origin and skin colour of the berries, is given in Tables 2 and 3, which also contain the results of the study.

\subsection{Assessment of Infestation and Cultivar Features}

The results from the three years when sour rot caused severe bunch injuries were analyzed in detail. In years with severe rot, three grape samples (each with at least ten 
bunches representative of the cultivar) were taken from each of the plots (cultivars), from the three plants being assessed. Degree of infestation by sour rot, expressed as percentage of cluster area with sour rot, was estimated on all bunches, at full maturity of the berries. To determine the level of infestation, the ratio of the number of external infested berries to the total number of external berries in the cluster was calculated. Cultivar resistance was evaluated using percentage of cluster area with sour rot, obtained in present study, and an adapted, 9-point scale published in the OIV Descriptor List, characteristic 459, which was originally used to describe bunch resistance to Botrytis [29]. Cultivars were divided into classes, where values characterize resistance to bunch sour rot, on a scale of $1-9$, as given below:

- $\quad$ very little and little resistance (1-4 = many wilted or rotten berries on all clusters, all clusters are attacked, some of them can be slightly affected);

- medium (5-6 = large percentage of wilted or rotten clusters (up to 20\%)-most clusters are moderately attacked, only a few clusters are attacked more severely);

- $\quad$ high and very high (7-9 = only a few wilted or rotten berries on all clusters, only single clusters are slightly attacked).

During the research, selected features related to the morphology, phenology and ecology of the grapevine cultivars were evaluated, which, according to the literature data, may affect the degree of sour rot infestation. Five features were assessed according to the OIV Descriptor List (called further OIV) on 9-point scales [29]:

- $\quad$ density of bunch (OIV, character 204) -1 (very loose) = berries clearly separated, many visible pedicels; 3 (loose) $=$ berries in loose contact with each other with some visible pedicels; $5($ medium $)=$ densely distributed berries, pedicels not visible, berries are movable; 7 (dense) $=$ berries not readily movable; 9 (very dense $)=$ berries deformed by compression;

- $\quad$ thickness of berry skin (OIV, character 228)—1 (very thin); 3 (thin); 5 (medium); 7 (thick); 9 (very thick). The evaluation was carried out in relation to reference cultivars;

- $\quad$ time of beginning of berry ripening (veraison) (OIV, character 303)-1 (very early); 3 (early); 5 (medium); 7 (late); 9 (very late);

- $\quad$ single bunch weight (OIV, character 502) 1 (very low) = up to about $100 \mathrm{~g} ; 3$ (low); 5 $($ medium $)=$ about $500 \mathrm{~g} ; 7$ (high); 9 (very high) = about $900 \mathrm{~g}$ and more;

- $\quad$ single berry weight (OIV, character 503) -1 (very low) = up to about $1 \mathrm{~g} ; 3$ (low); 5 $($ medium $)=$ about $5 \mathrm{~g} ; 7$ (high); 9 (very high) $=$ about $9 \mathrm{~g}$ and more.

Density of bunch, thickness of berry skin, single bunch weight and single berry weight were assessed at maturity. The time of the beginning of veraison for each cultivar was considered to be reached when about $50 \%$ of the plants reached this stage. During the berry ripening stage (veraison-maturity), additional features of berries were also assessed, such as: easy detachment of the berry from pedicel or berry drop, sensitivity to skin cracking, frequent insect damages, and sensitivity to sunburn. These traits were attributed to cultivars if they occurred at least twice in the 2017-2019 period, when the sour rot was severe.

\subsection{Statistical Analysis}

Data concerning infestation by sour rot, expressed as percentage of cluster area with sour rot, were analyzed statistically with the use of the variance analysis method which was applied to the values after Bliss' transformation. The significance of the means was evaluated using Student's t-test at the 5\% level. The correlation between infestation by sour rot, expressed as percentage of cluster area with sour rot and selected varietal traits (density of bunch, thickness of berry skin, time of beginning of veraison, single bunch weight, single berry weight), expressed as numbers from 1 to 9 , was assessed through the Pearson's linear correlation coefficient $(r)$. The strength of Pearson's linear correlation coefficient was rated as follows: $|r|$ : 0.0-0.2-very weak; 0.2-0.4-weak; 0.4-0.6-moderate; 0.6-0.8-strong; $0.8-1$ - very strong. 


\section{Results}

In 2017, 2018 and 2019, the infestation by sour rot was assessed as severe. In the remaining seasons $(2015,2016$ and 2020), the infestation was marginal or absent and the data relating to these years were not included in the presentation of the results. The mean infestation of bunches from the three selected years, together with the standard deviation, are presented separately for wine (Table 2) and table (Table 3) cultivars. The severity of infestation, expressed as a percentage of cluster area with sour rot, was used to divide the varieties according to the resistance class to sour rot. Among 28 wine cultivars, the number of cultivars in particular classes of resistance was as follows: very little or little-9, medium-9, high or very high-10. The cultivar 'Siegerrebe' was characterized by a very little resistance, and the cultivars 'Phoenix', 'Pinot Noir', 'Silvaner', 'Riesling', 'Calandro', 'Seyval', 'Reberger', 'Veltliner Frührot', by a little resistance. The wine cultivars with very high resistance were 'Bianca', 'Regent', 'Prior', 'Souvignier Gris', 'Marechal Foch', and 'Cabernet Cantor'. Among 25 table cultivars, the number of cultivars in particular classes of resistance was as follows: very little or little—9, medium-3, high or very high—13. 'Rusven', 'Piesnia', and 'Krasotka' belonged to table cultivars with very low resistance, whereas 'Festivee', 'Alden', and 'NY Muscat' belonged to cultivars with very high resistance.

Table 2. Severity of infestation and resistance of wine cultivars to sour bunch rot.

\begin{tabular}{|c|c|c|c|c|c|}
\hline Cultivar & $\begin{array}{l}\text { Colour of Berry } \\
\text { Skin * }\end{array}$ & Origin $* *$ & $\begin{array}{l}\text { Country of } \\
\text { Breeding }\end{array}$ & $\begin{array}{l}\text { Mean Severity of Sour } \\
\text { Rot-Cluster Area with } \\
\text { Sour Rot (\%) }\end{array}$ & $\begin{array}{l}\text { Class of Resistance to } \\
\text { Bunch Sour Rot }\end{array}$ \\
\hline Siegerrebe & $\mathrm{R}$ & Vin & Germany & $53.0 \pm 8.54 \mathrm{t}^{1}$ & VL (1) \\
\hline Phoenix & $\mathrm{B}$ & $\mathrm{IIH}$ & Germany & $40.6 \pm 9.61 \mathrm{~s}$ & $\mathrm{~L}(2)$ \\
\hline Pinot Noir & $\mathrm{N}$ & Vin & France & $31.2 \pm 7.57 \mathrm{r}$ & L (3) \\
\hline Silvaner & $\mathrm{B}$ & $\operatorname{Vin}$ & Austria & $28.2 \pm 6.81 \mathrm{qr}$ & L (3) \\
\hline Riesling & B & Vin & Germany & $25.2 \pm 5.13 \mathrm{pq}$ & L (3) \\
\hline Calandro & $\mathrm{N}$ & $\mathrm{IIH}$ & Germany & $23.5 \pm 5.03$ op & L (4) \\
\hline Seyval & $\mathrm{B}$ & $\mathrm{IH}$ & France & $22.2 \pm 5.13 \mathrm{n}-\mathrm{p}$ & L (4) \\
\hline Reberger & $\mathrm{N}$ & $\mathrm{IIH}$ & Germany & $21.2 \pm 5.69 \mathrm{~m}-\mathrm{o}$ & L (4) \\
\hline Veltliner Frührot & $\mathrm{R}$ & Vin & Austria & $20.4 \pm 6.43$ 1-о & $\mathrm{L}(4)$ \\
\hline Domina & $\mathrm{N}$ & Vin & Germany & $19.8 \pm 5.001-n$ & M (5) \\
\hline Pinot Blanc & $\mathrm{B}$ & Vin & France & $18.6 \pm 3.51 \mathrm{~lm}$ & $M(5)$ \\
\hline Villaris & $\mathrm{B}$ & $\mathrm{IIH}$ & Germany & $17.3 \pm 5.57 \mathrm{kl}$ & M (5) \\
\hline Tauberschwarz & $\mathrm{N}$ & $\operatorname{Vin}$ & Germany & $17.2 \pm 3.06 \mathrm{kl}$ & $M(5)$ \\
\hline Cabernet Cortis & $\mathrm{N}$ & $\mathrm{IIH}$ & Germany & $15.4 \pm 5.03 \mathrm{jk}$ & M (5) \\
\hline Solaris & $\mathrm{B}$ & $\mathrm{IIH}$ & Germany & $14.7 \pm 5.57 \mathrm{i}-\mathrm{k}$ & $M(6)$ \\
\hline Rondo & $\mathrm{N}$ & IIH & Germany & $13.2 \pm 4.16 \mathrm{~h}-\mathrm{j}$ & $M(6)$ \\
\hline Johanniter & $\mathrm{B}$ & $\mathrm{IIH}$ & Germany & $12.1 \pm 4.58 \mathrm{hi}$ & $M(6)$ \\
\hline Pinot Gris & $\mathrm{R}$ & Vin & France & $11.5 \pm 4.04 \mathrm{gh}$ & $M(6)$ \\
\hline Pinot Meunier & $\mathrm{N}$ & Vin & France & $9.5 \pm 3.06 \mathrm{fg}$ & $\mathrm{H}(7)$ \\
\hline Hibernal & $\mathrm{B}$ & IIH & Germany & $8.8 \pm 3.00 \mathrm{f}$ & $\mathrm{H}(7)$ \\
\hline Felicia & B & $\mathrm{IIH}$ & Germany & $4.6 \pm 1.53 \mathrm{e}$ & $\mathrm{H}(7)$ \\
\hline Traminer Rot & $\mathrm{R}$ & Vin & France & $2.9 \pm 1.00 \mathrm{~d}$ & $\mathrm{H}(7)$ \\
\hline Bianca & $\mathrm{B}$ & $\mathrm{IH}$ & Hungary & $1.9 \pm 1.00 \mathrm{~cd}$ & $\mathrm{VH}(8)$ \\
\hline Regent & $\mathrm{N}$ & $\mathrm{IIH}$ & Germany & $1.5 \pm 1.15 c$ & VH (8) \\
\hline Prior & $\mathrm{N}$ & IIH & Germany & $0.4 \pm 0.58 \mathrm{~b}$ & $\mathrm{VH}(8)$ \\
\hline Souvignier Gris & $\mathrm{R}$ & $\mathrm{IIH}$ & Germany & $0.1 \pm 0.58 \mathrm{ab}$ & $\mathrm{VH}(8)$ \\
\hline Marechal Foch & $\mathrm{N}$ & $\mathrm{IH}$ & France & $0.1 \pm 0.58 \mathrm{ab}$ & $\mathrm{VH}(8)$ \\
\hline Cabernet Cantor & $\mathrm{N}$ & $\mathrm{IIH}$ & Germany & $0.0 \pm 0.00 \mathrm{a}$ & $\mathrm{VH}(9)$ \\
\hline
\end{tabular}

${ }^{1}$ Means followed by the same letter do not differ significantly at $p=0.05$. Values with the prefix \pm represent standard deviation. ${ }^{*}$ Colour of berry skin: B (blanc)—green-yellow, R—rose, $\mathrm{N}$ (noir)—blue-black. ** Origin: Vin-V. vinifera; IH—interspecific hybrid from crossing $V$. vinifera and species from among V. riparia, V. rupestris, V. lincecumii, V. amurensis, V. labrusca; IIH-inter-intraspecific (intra- interspecific) hybrid from crossing interspecific hybrid and V. vinifera. *** Class of bunch sour rot resistance, with values on a scale of 1-9 in the brackets: VL-very little and L-little (1-4 = many wilted or rotten berries on all clusters (all clusters are attacked, some of them can be slightly affected); M-medium (5-6 = large percentage of wilted or rotten clusters (up to 20\%)-most clusters are moderately attacked, only few clusters are attacked more severely); $\mathrm{H}-$ high and $\mathrm{VH}$ - very high (7-9 = only a few wilted or rotten berries on all clusters, only single clusters are slightly attacked). 
Table 3. Severity of infestation and resistance of table cultivars to sour bunch rot.

\begin{tabular}{|c|c|c|c|c|c|}
\hline Cultivar & $\begin{array}{l}\text { Colour of Berry } \\
\text { Skin * }\end{array}$ & Origin $* *$ & $\begin{array}{l}\text { Country of } \\
\text { Breeding }\end{array}$ & $\begin{array}{c}\text { Mean Severity of Sour } \\
\text { Rot-Cluster Area with } \\
\text { Sour Rot (\%) }\end{array}$ & $\begin{array}{l}\text { Class of Sour Rot } \\
\text { Resistance } * * *\end{array}$ \\
\hline Rusven & B & $\mathrm{IH}$ & Russia & $62.2 \pm 10.5 \mathrm{n}^{1}$ & VL (1) \\
\hline Piesnia & $\mathrm{B}$ & $\mathrm{IH}$ & Russia & $55.8 \pm 13.0 \mathrm{mn}$ & VL (1) \\
\hline Krasotka & $\mathrm{R}$ & $\mathrm{IH}$ & Russia & $54.1 \pm 9.54 \mathrm{~lm}$ & VL (1) \\
\hline Argo & $\mathrm{R}$ & $\mathrm{IH}$ & Ukraine & $49.7 \pm 11.6 \mathrm{~lm}$ & $\mathrm{~L}(2)$ \\
\hline Galbena Nou & B & $\mathrm{IH}$ & Russia & $48.0 \pm 10.41$ & $\mathrm{~L}(2)$ \\
\hline Reliance & $\mathrm{R}$ & $\mathrm{IH}$ & USA & $39.6 \pm 8.62 \mathrm{k}$ & $\mathrm{L}(3)$ \\
\hline Galanth & $\mathrm{N}$ & $\mathrm{IH}$ & Germany & $37.9 \pm 9.17 \mathrm{k}$ & L (3) \\
\hline Aron & $\mathrm{B}$ & $\mathrm{IH}$ & Hungary & $26.2 \pm 11.6 \mathrm{j}$ & L (3) \\
\hline Evita & B & $\mathrm{IH}$ & Austria & $22.8 \pm 7.00 \mathrm{ij}$ & $\mathrm{L}(4)$ \\
\hline Sophie & B & $\mathrm{IH}$ & Hungary & $19.5 \pm 5.03 \mathrm{hi}$ & $M(5)$ \\
\hline Garantos & $\mathrm{B}$ & $\mathrm{IH}$ & Germany & $16.5 \pm 4.51 \mathrm{gh}$ & $M(5)$ \\
\hline Antracyt & $\mathrm{N}$ & $\mathrm{IH}$ & Russia & $12.3 \pm 2.52 \mathrm{fg}$ & $M(6)$ \\
\hline Palatina & $\mathrm{B}$ & $\mathrm{IH}$ & Hungary & $9.9 \pm 1.53 \mathrm{f}$ & $\mathrm{H}(7)$ \\
\hline Nero & $\mathrm{N}$ & $\mathrm{IH}$ & Hungary & $8.6 \pm 2.08$ ef & $\mathrm{H}(7)$ \\
\hline Arkadia & $\mathrm{B}$ & $\mathrm{IH}$ & Ukraine & $8.3 \pm 1.53$ ef & $\mathrm{H}(7)$ \\
\hline Price & $\mathrm{N}$ & $\mathrm{IH}$ & USA & $5.6 \pm 1.53 \mathrm{de}$ & $\mathrm{H}(7)$ \\
\hline Muscat Bleu & $\mathrm{N}$ & $\mathrm{IH}$ & Switzerland & $4.9 \pm 1.00 \mathrm{~cd}$ & $\mathrm{H}(7)$ \\
\hline Vostorg & B & $\mathrm{IH}$ & Russia & $4.6 \pm 1.53 \mathrm{~cd}$ & $\mathrm{H}(7)$ \\
\hline Jupiter & $\mathrm{R}-\mathrm{N}$ & $\mathrm{IH}$ & USA & $3.6 \pm 1.53 \mathrm{~b}-\mathrm{d}$ & $\mathrm{H}(7)$ \\
\hline Chasselas Dore & B & Vin & France & $3.3 \pm 0.58 \mathrm{~b}-\mathrm{d}$ & $\mathrm{H}(7)$ \\
\hline Suzi & B & $\mathrm{IH}$ & Hungary & $2.9 \pm 1.00 \mathrm{bc}$ & $\mathrm{H}(7)$ \\
\hline Somerset Sdl & $\mathrm{R}$ & $\mathrm{IH}$ & USA & $2.6 \pm 1.15 b c$ & $\mathrm{H}(7)$ \\
\hline Festivee & $\mathrm{N}$ & $\mathrm{IH}$ & Canada & $1.5 \pm 1.15 \mathrm{~b}$ & VH (8) \\
\hline Alden & $\mathrm{N}$ & $\mathrm{IH}$ & USA & $0.2 \pm 1.15 \mathrm{a}$ & VH (9) \\
\hline NY Muscat & $\mathrm{R}-\mathrm{N}$ & $\mathrm{IH}$ & USA & $0.0 \pm 0.00 \mathrm{a}$ & VH (9) \\
\hline
\end{tabular}

${ }^{1}$ Means followed by the same letter do not differ significantly at $p=0.05$. Values with the prefix \pm represent standard deviation. ${ }^{*}$ Colour of berry skin: B (blanc)—green-yellow, R—rose, N (noir)—blue-black; ${ }^{* *}$ Origin: Vin-V. vinifera; IH-interspecific hybrid from crossing $V$. vinifera and species from among V. riparia, V. rupestris, V. lincecumii, V. amurensis, V. labrusca; *** Class of bunch sour rot resistance, with values on a scale of 1-9 in the brackets: VL-very little and L-little (1-4 = many wilted or rotten berries on all clusters (all clusters are attacked, some of them can be slightly affected); M-medium (5-6 = large percentage of wilted or rotten clusters (up to $20 \%)-$ most clusters are moderately attacked, only few clusters are attacked more severely); H—high and VH—very high (7-9 = only a few wilted or rotten berries on all clusters, only single clusters are slightly attacked).

The differentiation of selected features related to morphology, biology and ecology are presented separately for wine (Table 4) and table (Table 5) cultivars. The assessed wine cultivars were characterized by a significant variation in the density of grapes, from loose ('Cabernet Cantor', 'Marechal Foch') to very dense ('Silvaner', 'Johanniter'); skin thickness, from thin ('Siegerrebe', 'Phoenix', 'Pinot Noir') to thick ('Souvignier Gris') and the time of the beginning of veraison, from very early ('Siegerrebe') to medium ('Silvaner', 'Riesling', 'Johanniter', 'Traminer Rot', 'Souvignier Gris'). The diversity of wine cultivars in terms of weight of single bunch was small, from very low ('Pinot Noir', 'Riesling', 'Pinot Meunier', 'Traminer Rot', 'Marechal Foch '), to low ('Phoenix', 'Souvignier Gris'), as was the weight variation of single berry, from very low ('Marechal Foch') to low ('Phoenix'). Table cultivars were clearly differentiated in terms of the density of the grapes, from very loose-loose ('NY Muscat') to dense ('Aron'); thickness of skin, from very thin-thin ('Rusven') to mediumthick ('Festivee', 'Alden', 'NY Muscat' ) and the time of the beginning of veraison, from very early ('Krasotka', 'Galbena Nou', 'Nero', 'Somerset Sdl') to medium ('Aron', 'Sophie', 'Festivee', 'Alden'). In terms of a weight of single bunch, which rated from very low ('Somerset Sdl') to medium-high ('Aron'), and weight a of single berry, which ranged from very small ('Somerset Sdl') to medium-large ('Piesnia'), table cultivars were more varied than wine varieties.

Both wine and table cultivars were clearly differentiated in terms of the presence of such features as easy detachment of the berry from the pedicel or berry drop, sensitivity to berry skin cracking, frequent insect damage, and sensitivity to sunburn (Tables 4 and 5). 
The skin of berries cracked in humid weather, especially when it followed a period of drought. Damage to the fruit was caused by insects such as wasps, hornets and bees. In the clusters of the 'Antracyt' cultivar, hornets were the first and most dangerous pests. Drosophila suzuki is not yet common in Poland and has not been found in the location where the present research was conducted. In the cultivars 'Reliance Sdl' and 'Price', an accumulation of as many as three unfavorable features was observed (easy detachment of berry from pedicel or berry drop, sensitivity to berry skin cracking, frequent damage to the skin by insects), while in others (e.g., 'Souvignier Gris', 'Cabernet Cantor', 'Chasselas Dore', 'Alden'), no such threats were observed.

The values obtained by Pearson's linear correlation coefficient showed a relationship between the severity of infestation, expressed as percentage of cluster area with sour rot and the selected varietal traits (Table 6). These relationships were similar for wine and table cultivars. Severity of bunch sour rot was positively correlated with bunch density and single bunch weight (very weak correlation for wine cultivars and weak correlation for table cultivars) and with single berry weight (moderate correlation for wine cultivars and weak correlation for table cultivars). Severity of sour rot was negatively correlated with thickness of berry skin (strong correlation) and the time of the beginning of veraison (weak correlation).

Table 4. Morphological, agrobiological and ecological features of wine cultivars.

\begin{tabular}{|c|c|c|c|c|c|c|}
\hline Cultivar & $\begin{array}{l}\text { Bunch } \\
\text { Density }\end{array}$ & $\begin{array}{l}\text { Thickness of } \\
\text { Berry Skin }\end{array}$ & $\begin{array}{c}\text { Time of Veraison } \\
\text { Beginning }\end{array}$ & $\begin{array}{l}\text { Single Bunch } \\
\text { Weight }\end{array}$ & $\begin{array}{l}\text { Single Berry } \\
\text { Weight }\end{array}$ & $\begin{array}{c}\text { Additional } \\
\text { Features }\end{array}$ \\
\hline Siegerrebe & 5 & 3 & 1 & 1.4 & 2.4 & $\mathrm{c}$ \\
\hline Phoenix & 5 & 3 & 2 & 1.9 & 2.9 & $c, d$ \\
\hline Pinot Noir & 7 & 3 & 3 & 1.0 & 1.3 & $\mathrm{~d}$ \\
\hline Silvaner & 9 & 6 & 5 & 1.5 & 1.6 & - \\
\hline Riesling & 7 & 5 & 5 & 1.0 & 1.5 & $\mathrm{~d}$ \\
\hline Calandro & 7 & 4 & 4 & 1.1 & 1.5 & - \\
\hline Seyval & 7 & 3 & 4 & 1.5 & 1.6 & $b, d$ \\
\hline Reberger & 5 & 5 & 3 & 1.7 & 1.6 & $\mathrm{~d}$ \\
\hline Veltliner Frührot & 7 & 5 & 3 & 1.1 & 1.4 & $\mathrm{c}$ \\
\hline Domina & 8 & 4 & 3 & 1.2 & 1.2 & $\mathrm{~d}$ \\
\hline Pinot Blanc & 7 & 4 & 3 & 1.4 & 1.5 & $\mathrm{~d}$ \\
\hline Villaris & 5 & 4 & 4 & 1.1 & 2.2 & $c, d$ \\
\hline Tauberschwarz & 5 & 5 & 4 & 1.2 & 2.3 & $\mathrm{~d}$ \\
\hline Cabernet Cortis & 6 & 5 & 4 & 1.8 & 1.3 & $\mathrm{~d}$ \\
\hline Solaris & 6 & 4 & 2 & 1.2 & 1.4 & $c, d$ \\
\hline Rondo & 6 & 5 & 2 & 1.2 & 1.7 & $\mathrm{~d}$ \\
\hline Johanniter & 9 & 5 & 5 & 1.1 & 1.2 & $\mathrm{~d}$ \\
\hline Pinot Gris & 7 & 5 & 3 & 1.1 & 1.2 & - \\
\hline Pinot Meunier & 9 & 5 & 4 & 1.0 & 1.1 & - \\
\hline Hibernal & 7 & 5 & 4 & 1.2 & 1.1 & $\mathrm{~d}$ \\
\hline Felicia & 6 & 4 & 2 & 1.3 & 2.1 & $c, d$ \\
\hline Traminer Rot & 6 & 6 & 5 & 1.0 & 1.4 & - \\
\hline Bianca & 5 & 6 & 4 & 1.3 & 1.9 & $\mathrm{~d}$ \\
\hline Regent & 4 & 6 & 4 & 1.2 & 1.8 & - \\
\hline Prior & 7 & 6 & 4 & 1.6 & 1.6 & - \\
\hline Souvignier Gris & 7 & 7 & 5 & 1.9 & 1.5 & - \\
\hline Marechal Foch & 3 & 4 & 2 & 1.0 & 1.0 & - \\
\hline Cabernet Cantor & 2 & 6 & 4 & 1.2 & 1.3 & - \\
\hline
\end{tabular}

Density of bunch: 1-very loose, 3-loose, 5-medium, 7-dense, 9-very dense. Thickness of berry skin: 1-very thin, 3-thin, 5medium, 7-thick, 9-very thick. Time of veraison beginning: 1-very early, 3-early, 5-medium, 7-late, 9-very late. Single bunch weight: 1 (very low)—up to about $100 \mathrm{~g}, 3$ (low)—about $300 \mathrm{~g} ; 5$ (medium), 7 (high), 9 (very high)—about $900 \mathrm{~g}$ and more. Single berry weight: 1 (very low) —up to about $1 \mathrm{~g}, 3$ (low)—about $3 \mathrm{~g}, 5$ (medium), 7 (high), 9 (very high)—about $9 \mathrm{~g}$ and more. Additional features of berries: $\mathrm{b}$ - sensitivity to skin cracking; $\mathrm{c}$ - frequent damage to the skin by insects; $\mathrm{d}$ - sensitivity to sunburn. 
Table 5. Morphological, agrobiological and ecological features of table cultivars.

\begin{tabular}{|c|c|c|c|c|c|c|}
\hline Cultivar & $\begin{array}{l}\text { Bunch } \\
\text { Density }\end{array}$ & $\begin{array}{l}\text { Thickness of } \\
\text { Berry Skin }\end{array}$ & $\begin{array}{c}\text { Time of Veraison } \\
\text { Beginning }\end{array}$ & $\begin{array}{l}\text { Single Bunch } \\
\text { Weight }\end{array}$ & $\begin{array}{l}\text { Single Berry } \\
\text { Weight }\end{array}$ & $\begin{array}{c}\text { Additional } \\
\text { Features }\end{array}$ \\
\hline Rusven & 6 & 2 & 2 & 2.5 & 5.0 & $b, c$ \\
\hline Piesnia & 5 & 3 & 2 & 3.5 & 6.0 & c \\
\hline Krasotka & 3 & 2 & 1 & 2.5 & 5.1 & $\mathrm{~b}$ \\
\hline Argo & 3 & 2 & 2 & 2.8 & 5.9 & $b, c$ \\
\hline Galbena Nou & 5 & 3 & 1 & 3.5 & 5.5 & $c, d$ \\
\hline Reliance & 5 & 3 & 2 & 1.4 & 2.5 & $a, b, c$ \\
\hline Galanth & 6 & 3 & 2 & 2.9 & 2.6 & $c, d$ \\
\hline Aron & 7 & 4 & 5 & 5.4 & 4.5 & - \\
\hline Evita & 5 & 3 & 3 & 3.5 & 3.7 & $c, d$ \\
\hline Sophie & 6 & 3 & 5 & 4.5 & 4.7 & - \\
\hline Garantos & 6 & 3 & 2 & 2.3 & 3.1 & $c, d$ \\
\hline Antracyt & 5 & 3 & 3 & 3.8 & 5.2 & c \\
\hline Palatina & 5 & 3 & 2 & 2.2 & 2.5 & $c, d$ \\
\hline Nero & 5 & 3 & 1 & 1.8 & 2.6 & C \\
\hline Arkadia & 4 & 3 & 2 & 3.5 & 5.4 & $\mathrm{~d}$ \\
\hline Price & 5 & 3 & 2 & 1.0 & 3.1 & $a, b, c$ \\
\hline Muscat Bleu & 3 & 4 & 2 & 3.2 & 4.9 & c \\
\hline Vostorg & 4 & 4 & 2 & 3.5 & 4.9 & d \\
\hline Jupiter & 4 & 4 & 2 & 2.0 & 4.5 & $\mathrm{a}$ \\
\hline Chasselas Dore & 5 & 3 & 3 & 1.5 & 3.0 & - \\
\hline Suzi & 5 & 4 & 4 & 3.5 & 4.3 & - \\
\hline Somerset Sdl & 5 & 4 & 1 & 1.0 & 1.5 & - \\
\hline Festivee & 3 & 6 & 5 & 1.9 & 5.5 & - \\
\hline Alden & 4 & 6 & 5 & 2.8 & 4.7 & - \\
\hline NY Muscat & 2 & 6 & 3 & 1.6 & 3.4 & - \\
\hline
\end{tabular}

Density of bunch: 1-very loose, 3-loose, 5-medium, 7-dense, 9-very dense. Thickness of berry skin: 1-very thin, 3-thin, 5medium, 7-thick, 9-very thick. Time of veraison beginning: 1-very early, 3-early, 5-medium, 7-late, 9-very late. Single bunch weight: 1 (very low)—up to about $100 \mathrm{~g}, 3$ (low)—about $300 \mathrm{~g} ; 5$ (medium), 7 (high), 9 (very high)—about $900 \mathrm{~g}$ and more. Single berry weight: 1 (very low)—up to about $1 \mathrm{~g}, 3$ (low)—about $3 \mathrm{~g}, 5$ (medium), 7 (high), 9 (very high)—about $9 \mathrm{~g}$ and more. Additional features: a — easy detachment of berry from pedicel or berry drop; $b$ - sensitivity to berry skin craking; $c$-frequent damage to the skin by insects; d-sensitivity to sunburn.

Table 6. Correlation between severity of bunch sour rot and selected varietal traits.

\begin{tabular}{ccc}
\hline \multirow{2}{*}{ Varietal Trait } & \multicolumn{2}{c}{ Pearson's Linear Correlation Coefficient $(\boldsymbol{r})$} \\
\cline { 2 - 3 } & Wine Cultivars & Table Cultivars \\
\hline Bunch density & 0.18 & 0.23 \\
Thickness of berry skin & -0.67 & -0.65 \\
Time of beginning of veraison & -0.37 & -0.33 \\
Single bunch weight & 0.17 & 0.23 \\
Single berry weight & 0.46 & 0.34 \\
\hline
\end{tabular}

Strength of Pearson's linear correlation coefficient $|r|: 0.0-0.2$-very weak; 0.2-0.4-weak; 0.4-0.6-moderate; $0.6-0.8$ - strong; $0.8-1$-very strong.

\section{Discussion}

The degree of infestation of grapes by sour rot varied between years and was high in the years with heavy rainfall, falling between veraison and fruit maturity, which is consistent with the reports of other authors $[17,20,26]$. In the present research, the clusters were more severely infected in the years 2017, 2018, and 2019, which were characterized by abundant rainfall in the August-September period (in 2018, also in July), greater than both the long-term average and rainfall in 2015, 2016 and 2020 in which the sour rot infestation was marginal. A comparison of varieties with diverse geographic and genetic origins showed the differences in the resistance of assessed genotypes to sour rot. The sensitive wine cultivars included the $V$. vinifera genotypes, interspecific hybrids, and interintraspecific (intra-interspecific) hybrids. The present study confirmed the reports of other 
authors that the basic factor determining the resistance to sour rot are the morphological and anatomical features of bunches and berries. The cultivars with dense clusters and thin skin should be considered the most sensitive [5], while the cultivars with loose clusters and thick skin of berries are characterized by greater resistance [20]. The present results, as well as previous reports, showed the low resistance of 'Riesling' [5,25], 'Pinot Noir' [5] and 'Seyval' [26]. On the other hand, the cultivars 'Pinot Gris' and 'Gewürztraminer' ('Traminer

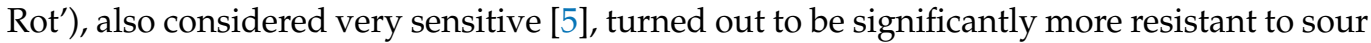
rot than 'Riesling' and 'Pinot Noir' in the present research. 'Pinot Gris' and 'Traminer Rot' have slightly thicker berry skin (5,6 respectively) compared to 'Pinot Noir' and 'Riesling' ( 3 and 5 respectively), slightly lower single berry weight, and were not prone to any skin damage (such as sunburn in the case of both, 'Pinot Noir' and 'Riesling'). Additionally, most of the other wine cultivars assessed, with the exception of 'Siegerrebe', 'Phoenix', and 'Silvaner', were more resistant to sour rot than 'Riesling' and 'Pinot Noir', and the resistance of 'Calandro' and 'Seyval' did not differ significantly from that of 'Riesling'. Cultivars such as 'Phoenix', 'Calandro', 'Seyval', and 'Reberger' have resistance gene loci for powdery and/or downy mildew and proved to be susceptible to sour rot [28]. 'Regent', 'Prior', 'Souvignier Gris', 'Cabernet Cantor' also have resistance loci and were highly resistant to sour rot in the present study. This indicates that cultivars selected for resistance to powdery and downy mildew may have other drawbacks and might be interesting for future studies related to climate change and site-specific pathogens.

Five table cultivars with the lowest resistance to sour rot originated from Russia or Ukraine, countries where a continental climate with dry summer prevails. The results concerning the resistance of table cultivars are difficult to relate to the data from the literature, which are sparse. The berries of the table cultivar 'Red Globe' ( $V$. vinifera) were solely used as experimental material and were infected with sour rot [6].

The severity of bunch sour rot for wine and table cultivars was positively, very weakly or weakly correlated with bunch density and single bunch weight. The correlation between severity of sour rot and single berry weight was positive, with moderate strength for wine cultivars and with little strength for table cultivars. These data are consistent with the earlier reports that the sensitivity of bunches to rot caused by Botrytis cinerea increases with their density and weight [23] and with the weight of berries [24]. Severity of sour rot was negatively and strongly correlated with thickness of berry skin. Among the examined features, this parameter was probably the most decisive in determining the resistance to sour rot. Resistance to grape rot caused by fungal pathogens Rhizopus stolonifer and Botrytis cinerea is related to the thickness of the skin [21,22]. The mechanism of resistance to rotting of bunches, regardless of its cause, seems to be similar.

Severity of sour rot was negatively, although weakly, correlated with the time of the beginning of veraison. This is in line with reports that early maturing cultivars are more sensitive to sour rot than late ones [5]. The main reason for this relationship is probably that the early beginning of veraison and the associated increase in extract content above $15^{\circ}$ Brix, occurs in the second half of July or at the beginning of August (northern hemisphere), when temperatures are high, which favors the rapid development of sour rot [5].

Morphological and anatomical features should not be the only determinant of resistance to sour rot. One should agree with the statement that sour rot may also appear on cultivars that are not early maturing and do not have dense clusters and thin skin [5]. This is due to the complex etiology of the disease, since organisms associated with sour rot (yeasts, bacteria, and D. melanogaster flies) must come in contact with the pulp through wounds $[3,7,10]$ or through the place where the berry is attached to the pedicel [3]. The obtained results indicate, according to the literature data, that infestation by sour rot is favored by such agrobiological and ecological characteristics of the cultivars as easy detachment of berry from pedicel, sensitivity to skin cracking, frequent damage to the skin by insects, and sensitivity to sunburn $[3,7,11,16]$. Cultivars that did not exhibit these features were more resistant to sour rot in the conditions of the present research. Under the conditions of the present study, effective chemical control of downy and powdery mildew 
made it impossible to establish a correlation between the degree of the mentioned fungal infections of the assessed cultivars and the degree of sour rot.

It is advisable to recommend varieties resistant to sour rot for cultivation in regions where it occurs frequently. This can reduce the losses caused by this type of rot and facilitate the integrated protection against sour rot, which consists of using microbials limiting the development of yeasts and bacteria and combating Drosophila flies and other insects control, which is preferable over fungal control, when it comes to sour rot symptom development $[5,6,17,20,30]$, using indirect methods such as management of excessive vine vigor and leaf removal [31], loosening tight clusters with growth regulators [5,17,30] and employing calcium and other supplements to increase skin toughness [31], although calcium is not always effective [32]. Data concerning sour rot resistance can be obtained during the methodical evaluation of cultivars in places of future cultivation and can be included in the descriptions of varieties, as now are data on resistance to the most important fungal diseases, physiological disorders and low temperatures.

\section{Conclusions}

Sour rot was severe in years with abundant rainfall during the berry ripening stage. The cultivars differed significantly in their resistance to sour rot. Severity of bunch sour rot was positively, very weakly or weakly correlated with bunch density and single bunch weight. The correlation between severity of sour rot and single berry weight was positive, with moderate strength for wine cultivars and with little strength for table cultivars. Severity of sour rot was negatively correlated with thickness of berry skin (strong correlation) and the time of the beginning of veraison-early maturing cultivars were more susceptible (weak correlation). Such agrobiological and ecological characteristics of the cultivars as easy detachment of berry from pedicel, sensitivity to berry skin cracking, frequent damage to the skin by insects, and sensitivity to sunburn, favoured sour rot infestation.

Author Contributions: Conceptualization, methodology, formal Analysis, investigation, resources, data curation, writing-original draft preparation, writing-review \& editing-J.L.; review \& editing, funding acquisition-A.L. Both authors have read and agreed to the published version of the manuscript.

Funding: This research was funded by the Polish Ministry of Agriculture and Rural Development in the frame of the programme on protection of genetic resources of horticultural crops.

Data Availability Statement: Data is contained within the article.

Conflicts of Interest: The authors declare no conflict of interest.

\section{References}

1. Gustafsson, J.G.; Mårtensson, A. Potential for extending Scandinavian wine cultivation. Acta Agric. Scand. B 2005, $55,82-97$.

2. Rayne, S.; Forest, K.; Friesen, K.J. Projected climate change impacts on grape growing in the Okanagan Valley, British Columbia, Canada. Nature Preced. 2009. [CrossRef]

3. Gravot, E.; Blancard, D.; Fermaud, M.; Lonvaud, A.; Joyeux, A. Sour rot 1-Etiology: Research into causes of this form of rot in Bordeaux vineyards. Phytoma 2001, 543, 36-39.

4. Guerzoni, M.E.; Marchetti, R. Analysis of yeast flora associated with grape sour rot and of the chemical disease markers. Appl. Environ. Microbiol. 1987, 53, 571-576. [CrossRef] [PubMed]

5. McFadden-Smith, W.; Gubler, W.D. Sour Rot. In Compendium of Grape Diseases, Pests, and Disorders, 2nd ed.; Wilcox, W.F., Gubler, W.D., Uyemoto, J.K., Eds.; APS Press: St. Paul, MN, USA, 2015; pp. 87-90.

6. Hall, M.E.; Loeb, G.M.; Cadle-Davidson, L.; Evans, K.J.; Wilcox, W.F. Grape sour rot: A four-way interaction involving the host, yeast, acetic acid bacteria, and insects. Phytopatology 2018, 108, 1429-1442. [CrossRef] [PubMed]

7. Bisiach, M.; Minervini, G.; Zerbetto, F. Possible integrated control of grapevine sour rot. Vitis 1986, 25, 118-128.

8. Barata, A.; Pais, A.; Malfeito-Ferreira, M.; Loureiro, V. Influence of sour rotten grapes on the chemical composition and quality of grape must and wine. Eur. Food Res.Technol. 2011, 233, 183-194. [CrossRef]

9. Marchetti, R.; Guerzoni, M.E.; Gentile, M. Research on the etiology of a new disease of grapes: Sour rot. Vitis 1984, $23,55-65$.

10. Loureiro, V.; Malfeito-Ferreira, M. Spoilage yeasts in the wine industry. Int. J. Food Microbiol. 2003, 86, 23-50. [CrossRef]

11. Barata, A.; Santos, S.C.; Malfeito-Ferreira, M.; Loureiro, V. New insights into the ecological interaction between grape berry microorganisms and Drosophila flies during the development of sour rot. Microb. Ecol. 2012, 64, 416-430. [CrossRef] 
12. Renouf, V.; Claisse, O.; Lonvaud-Funel, A. Understanding the microbial ecosystem on the grape berry surface through numeration and identification of yeast and bacteria. Aust. J. Grape Wine Res. 2005, 11, 316-327. [CrossRef]

13. Raspor, P.; Milek, D.M.; Polanc, J.; Mozina, S.S.; Cadez, N. Yeasts isolated from three varieties of grapes cultivated in different locations of the Dolenjska vine-growing region, Slovenia. Int. J. Food Microbiol. 2006, 109, 97-102. [CrossRef] [PubMed]

14. Barata, A.; Seborro, F.; Belloch, C.; Malfeito-Ferreira, M.; Loureiro, V. Ascomycetous yeast species recovered from grapes damaged by honeydew and sour rot. J. Appl. Microbiol. 2008, 104, 1182-1191. [CrossRef]

15. Barata, A.; Malfeito-Ferreira, M.; Loureiro, V. Changes in sour rotten grape berry microbiota during ripening and wine fermentation. Int. J. Food Microbiol. 2012, 153, 152-161. [CrossRef]

16. Barata, A.; Malfeito-Ferreira, M.; Loureiro, V. The microbial ecology of wine grape berries. Int. J. Food Microbiol. 2012, 153, 243-259. [CrossRef]

17. Huber, C. Etiology and Management of Grape Sour Rot. Ph.D. Thesis, Dept of Biological Sciences, Brock University, St. Catharines, ON, Canada, 2016.

18. Gadoury, D.M.; Seem, R.C.; Wilcox, W.F.; Henick-Kling, T.; Conterno, L.; Day, A.; Ficke, A. Effects of diffuse colonization of grape berries by Uncinula necator on bunch rots, berry microflora, and juice and wine quality. Phytopathology 2007, 97, 1356-1365. [CrossRef]

19. Rombaut, A.; Guilhot, R.; Xuéreb, A.; Benoit, L.; Chapuis, M.P.; Gibert, P.; Fellous, S. Invasive Drosophila suzukii facilitates Drosophila melanogaster infestation and sour rot outbreaks in the vineyards. R. Soc. 2017, 4, 170117. [CrossRef] [PubMed]

20. Vogel, A.; Breeden, S.; Brannen, P.; Blaauw, B.; Hickey, C. Grape Sour Rot. UGA Cooperative Extension Circular 1212.2020. Available online: https:/ / site.extension.uga.edu/viticulture/files/2020/09/Sour-Rot-Fact-Sheet.pdf (accessed on 16 June 2021).

21. Sarig, P.; Zutkhi, Y.; Lisker, N.; Shkelerman, Y.; Ben-Arie, R. Natural and induced resistance of table grapes to bunch rots. Acta Hortic. 1998, 464, 65-70. [CrossRef]

22. Gabler, F.M.; Smilanick, J.L.; Mansour, M.; Ramming, D.W.; Mackey, B.E. Correlations of morphological, anatomical and chemical features of grape berries with resistance to Botrytis cinerea. Phytopathology 2003, 93, 1263-1273. [CrossRef]

23. Vail, M.E.; Marois, J.J. Grape cluster architecture and the susceptibility of berries to Botrytis cinerea. Phytopatology 1991, 81, 188-191. [CrossRef]

24. Alonso-Villaverde, V.; Boso, S.; Santiago, J.L.; Gago, P.; Martínez, M.C. Relationship between susceptibility to Botrytis bunch rot and grape cluster morphology in the Vitis vinifera L. cultivar Albariño. Int. J. Fruit Sci. 2008, 8, 251-265. [CrossRef]

25. Zoecklein, B.W.; Williams, J.M.; Duncan, S.E. Effect of sour rot on the composition of white Riesling (Vitis vinifera) grapes. Small Fruits Rev. 2000, 1, 63-77. [CrossRef]

26. Bordelon, B. Grapes: The sour rot situation. In Facts for Fancy Fruits, 16-11; Purdue University: West Lafayette, IN, USA, 2016; pp. 1-4. Available online: https:/ / fff.hort.purdue.edu/article/grapes-the-sour-rot-situation/ (accessed on 16 June 2021).

27. Theocharis, A.; Hand, P.; Pole, J.; Cevik, V.; Fisarakis, I.; Henderson, J. Study of genetic diversity among inter-intraspecific hybrids and original grapevine varieties using AFLP molecular markers. Aust. J. Crop Sci. 2010, 4, 1-8.

28. Vitis International Variety Catalogue. Available online: www.vivc.de (accessed on 16 June 2021).

29. OIV. OIV Descriptor List for Grape Varieties and Vitis Species, 2nd ed.; OIV: Paris, France, 2001; p. 232.

30. Hall, M.E.; Loeb, G.M.; Wilcox, W.F. Control of sour rot using chemical and canopy management techniques. Am. J. Enol. Vitic. 2018, 69, 342-350. [CrossRef]

31. Duncan, R.A.; Stapleton, J.J.; Leavitt, G.M. Population dynamics of epiphytic microflora and occurrence of bunch rots of wine grapes as influenced by leaf removal. Plant Pathol. 1995, 44, 956-965. [CrossRef]

32. McFadden-Smith, W.; Huber, C.; Inglis, D. Summary of Results for Grape Sour Rot Project. Available online: http://www. grapegrowersofontario.com/node/454 (accessed on 26 July 2021). 